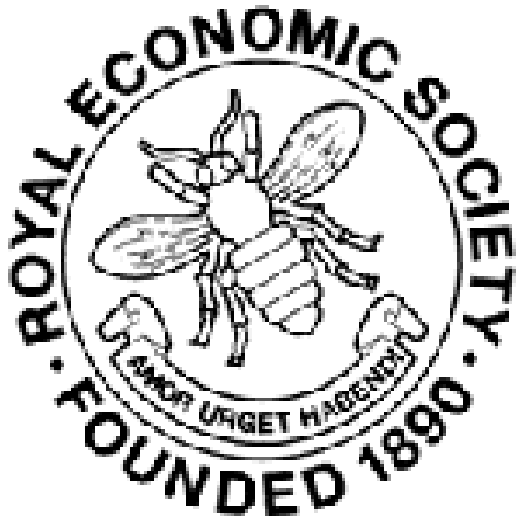

The Overproduction of Currants: A Novel Experiment in Protection

Author(s): T. A. B.

Source: The Economic Journal, Vol. 9, No. 36 (Dec., 1899), pp. 633-651

Published by: Wiley on behalf of the Royal Economic Society

Stable URL: http://www.jstor.org/stable/2956590

Accessed: 27-06-2016 02:37 UTC

Your use of the JSTOR archive indicates your acceptance of the Terms \& Conditions of Use, available at

http://about.jstor.org/terms

JSTOR is a not-for-profit service that helps scholars, researchers, and students discover, use, and build upon a wide range of content in a trusted digital archive. We use information technology and tools to increase productivity and facilitate new forms of scholarship. For more information about JSTOR, please contact support@jstor.org.

Royal Economic Society, Wiley are collaborating with JSTOR to digitize, preserve and extend access to The Economic Journal 
To sum up, we find domestic servants enjoying in Germany, as in other countries, great economic advantages over other workers. They are at a disadvantage compared with them in regard to legal protection, factory legislation, and, above all, in regard to freedom and privacy, and it seems without doubt that the latter causes have to answer for the unpopularity of the profession. We have seen that the disproportion between demand and supply is accompanied by less skilled workmanship and by the lack of inclination on the worker's part to fulfil those requirements which, on the part of the employers, are thought essential or even indispensable. The consequence of these conditions is general dissatisfaction amongst the mistresses and similar discontent amongst servants, which is growing with the spread of democratic and socialistic ideas, which begin to penetrate even this sphere.

The Domestic Servant question in Germany may not yet be such a burning one as it is in England or America; but it is certainly not an unimportant one, and students of economy begin to realise the importance of it. Palliative measures, such as concessions in the matter of hours, improved training, \&c., will hardly meet the case, and it will probably be true with regard to Germany, as it is of other countries, that nothing short of an entire change in the elements of the domestic system will settle this part of the labour question.

HenRiette Jastrow

\section{The Overproduction of Currants.}

\section{A Novel Experiment in Protection.}

THE problem connected with the protection of national industries, which the Governments of several countries have had to solve at various times, has been mainly this : how to protect the home producer in the home market against the competition of the foreigner; in other words, how to reserve the home market to the home producer by the exclusion of the foreigner. Upon the people and the Government of little Greece a more complex problem forced itself for solution six years ago. It was this: how to protect the producer of currants against himself, not in the home, but in the foreign markets.

It is not generally known to the consumers of currants in the United Kingdom that this delicious and wholesome fruit thrives and prospers only in certain districts of Greece, all attempts to transplant it in other lands of similar climatic conditions having failed. The history of currants goes back to the times of mythology. It is probable that the first wine which mankind ever tasted was made from dried grapes, such as currants. As the cradle of the vine, historians have successively accepted the lands by the banks of the Euphrates and

No. 36.-VOL. IX. $\mathrm{T}$ T 
by the shores of the Caspian Sea; the valleys of Yemen and of Arabia Felix ; the plains of Mingrelia and of Georgia ; of Armenia and of Tabriz; of Sennaar and of many other countries. This mass of suppositions is evidently responsible for the general belief that this precious as well as beautiful plant was at first reared in the temperate corner of Western Asia. It is surmised that the inhabitants of this part of the world made their wine, in prehistoric times, from grapes dried in the sun; and to the beverage thus obtained they attributed divine origin. Hence the ancient Greeks, for several centuries, gave the preference to wine made from dried to that made from fresh grapes. Theopompus says that the islanders of Chios were the first to plant the vine and to make wine from the grape, an art which was imparted to them by Enopœos, the son of Bacchus, and which they afterwards taught to other mortals. Another legend has it that Bacchus taught the art to Icarus as a reward for his hospitality to the vine-garlanded god. The nectar on the Olympian dinner table is believed to have been nothing. less than a decoction made of honey and of dried-grape wine. ${ }^{1}$ Pliny, writing in the first century of the Christian era, mentions the tiny Greek grape, of fine quality and of thin skin. Be this as it may, the Greeks of the present day will hear of no other land as the mother of the currant vine than the classic plains of Corinth, from which the product

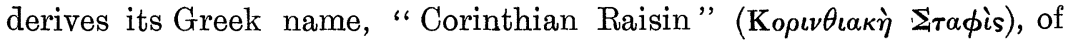
which the English word currants is, no doubt, a slight corruption.

During the Turkish occupation of the Peloponnesus the quantity of currants produced was very small. In 1825 , no more than about 1,000 tons were exported. In 1831, the production, outside the Ionian Islands, was under 2,500 tons. It rose to 6,500 in 1845 , to 27,000 in 1851 , and in 1860 to 52,000 , including 13,000 from the Ionian Islands. In 187181,000 , and in 1878101,000 tons were produced. In 1888 , the production, stimulated by the demand for wine making, of which more anon, attained 160,000 tons, and in 1895 it rose to 177,000 . Since then it has shown a slight diminution. The consumption kept pace with the increased production, and, excepting short intervals, the cultivation of the currant vine was giving a fair return to those engaged in it until the year 1893.

In 1871, the Hellenic Parliament passed an Act to facilitate the sale of national lands in small plots, with the object of promoting the creation of a class of peasant proprietors. The State offered the land at a very low price, payable in twenty-six yearly instalments, free of interest. As soon as the measure was passed all classes of the population, and especially the peasants, sent in their applications for allotment. The allotment to each citizen was limited to eighty stremmas, equal to about nineteen acres. In the following years a large area of this land, chiefly in Peloponnesus, was planted with currant vines, and when in the years 1877-8 these plants began to give full crops, the production overran the consumption; and the supply being in excess of the demand, prices

${ }^{1}$ Ariston of Chios. 
fell to the lowest level on record. In fact, in the spring of 1878, currants were offered in the London market at prices scarcely covering the freight paid to bring them from Greece.

At about this time a "deus ex machina," in the person of the French wine maker, appeared on the scene to save the Greek currant grower from the disastrous effects of his misdirected industry. The phylloxera had reduced the French vintage to less than one-half of its former yield, and to considerably less than what was required for the consumption of France itself. Various expedients were resorted to by the French wine trade to supply the deficiency, and amongst them was the natural and legitimate, and, therefore, the most successful, viz., the manufacture of wine from dried currants. ${ }^{1}$ The low price at which the currant merchants in London were compelled to sell their currants left a large profit to the French, who imported them free of duty and made them into wine in the South of France. Their phenomenal success stimulated the establishment of large currant-wine factories all over France ; and in spite of the imposition of a duty in 1882, equal to $2 s .4 d$. per ewt., the importation of currants went on increasing year by year until in 1889-90, France imported and turned into wine more than 70,000 tons of currants, a quantity equal to about one-half of the whole production. The fruit was used, not only by the manufacturers, but also, and in a large measure, by the wine growers, who had found in it the best material for supplying the deficiency caused through their diminished vintage, and the surest and purest strengthener of their weak and non-keeping wines. The class, however, to which more than to any other, currants proved an immense boon was the working class. With the expenditure of a few francs for the purchase of the currants, the working man in the large towns was able to make his own wine at home, purer and more wholesome than that which the wine merchant could offer him at five times the price.

The French are the best connoisseurs, and, next to the Spaniards, the largest wine-drinkers in the world. The wine made from currants soon became very popular in France. It was found to be far superior to the common natural wines in several respects, and especially in its keeping properties. The wine merchants paid higher prices for it than for the ordinary wines produced from fresh grapes. Meanwhile, the phylloxera had been partly conquered by the replanting of the devastated vineyards with the American plant, which had shown itself

(1) "Le phylloxéra dévastant les vignobles, on chercha un remède à ce fléau; ce reméde fut le RAISIN SEC. C'est à lui que beaucoup de nos compatriotes doivent d'avoir toujours eu du vin, quand les vignes dépérissaient dans nos campagnes. Les branches sans feuilles, les celliers vides, la futaille employée comme bois de chauffage parcequ'on n'avait plus rien pour la remplir; voilà quelle était la situ. ation lorsque survint le raisin sec. Il apparut véritablement comme un sauveur. De fait, il vainquait le phylloxéra en permettant d'attendre plus patiement la fin de la maladie; bien des vignerons furent ainsi préservés de la misère. Grâce à lui, l'invasion phylloxérique ne fut pas mortelle pour la viticulture française." ("Les Raisins Secs." Préface, v., par Paul de Sorgues et Raymond Berthault, Paris, 1890).

$\mathrm{T}$ T 2 
proof against the insect. The home production had begun to increase and the price to decrease. The wine growers, unable to get for their produce as much as they desired, looked out for the cause, and they thought that they found it in the foreign product, which a few years earlier they had welcomed as a friend and a saviour ${ }^{1}$. A violent agitation was set on foot, and in July 1889, the Chambers were compelled to yield to the clamour of ignorance, blinded by self-interest, and to pass the Griffe Act, known as such by the name of its sponsor, the late Senator Griffe. By this law, wine made from currants cannot be sold as "wine" without the seller incurring heavy penalties and imprisonment. The casks containing it must bear a special mark, or ticket, with the words " Currant Wine" in large letters.

The Griffe law having proved ineffective in raising the price of the home wine, the growers made a fresh demand, and the obliging legislature yielded again ; and in August, 1890, imposed a manufacturing duty on currant wine, equal to $4 s .8 d$. per cwt. of currants. In spite of this heavy duty the use of currants continued, although to a smaller extent. In February, 1892, the Meline Protective Tariff, raising the duty of almost everything, came into force. This tariff raised the import duty on currants from $2 s$. $4 d$. to $6 s$. per cwt., but the manufacturing duty was at the same time reduced to $1 s$. $7 d$. per cwt. Although the quantity of currants used for wine making had diminished materially after 1892 , the wine growers continued to denounce currants as their arch-enemy and the cause of all their ills, and eventually the import duty was again raised to $10 \mathrm{~s}$. per cwt. The duty having proved insufficient to kill the industry, the last blow was struck by the Turrel Act, passed in 1896, which assimilated currant wine to alcohol, and thus imposed a further duty, equal to $19 \mathrm{~s}$. per cwt., making in all $30 s .7 d$., or about 500 per cent. on the original value of the raw material. This Act went still further, it subjected the sale of currant wine to the regulations and restrictions affecting alcohol. The natural result of this persecution immediately followed. All currant-wine factories disappeared, and the importation of currants into France was reduced to the very small quantities required for eating purposes.

We have seen that France appeared as a consumer of currants in 1878, just at the nick of time to put an end to a crisis which threatened the existence of the weaker and most numerous class of currant growers. As soon as the danger passed and a market appeared to have been created for an unlimited quantity of currants at remunerative prices, this same class devoted itself unremittingly to the increase of currant plantations. Lacking the necessary capital, these small proprietors borrowed it of small local capitalists, at usurious interest, on the mortgage of their estates. So long as the price of their produce

"Les gros propriétaires qui, aux époques sombres où le phylloxéra ravageait leurs vignobles, soutenaient leur situation menacée et augmentaient leur rendement au moyen du raisin sec, sont à la tête du mouvement et demandent la proscription de leur sauveur de la veille." ("Les Raisins Secs." Préface, vii.) 
kept at a high level and enabled them to pay the interest on their debt and to leave a fair margin as a return for their personal labour, all went well. The mortgagee received his high interest, and was only too. pleased to continue the loan. The debtor was confident of the future, and his ambition was not how to reduce the incumbrance, but how to increase his production by fresh plantations, reared on more borrowed money. With these forces in operation, Greece produced in 1888 twice as many currants as in 1876 .

There were words of warning on several occasions. Every temporary fall in the price brought up to the surface a variety of expert opinion. In 1884, 1888, and in 1891, years of large crops and of comparatively low prices, many remedies were suggested. Some thought that the production should be restricted, but they refrained from proposing any practical means by which this end could be attained. Others proposed that currants, being a natural monopoly of Greece, should be made a State monopoly. The State should buy at certain fixed prices the whole crop, and then sell at a profit to the different countries of consumption as much of it as they required. The surplus, if any, was to be used for the production of wines and spirits in State factories. This scheme met with strenuous opposition from several quarters, and obtained scarcely any adherents. At the height of this currant crisis, in May, 1878, I myself proposed a plan. By a careful study of the subject I had satisfied myself that the then existing consumers of currants were willing to pay a good price for a certain quantity which they required; but that they would use no more, or very little more, even if the fruit were offered them at half that price. The crop of 1875, of 72,300 tons, realised an average price of over $23 s$. per cwt., in bond ; the crop of 1877 , of 80,860 tons, realised only about. $8 s$., or one-third of the price realised by the $1875 \mathrm{crop}$, though the supply in the latter year exceeded the requirements by about 10 per cent. only. It occurred to me then that this small excess, which affected the price of the whole crop to an extent ruinous to the growers, might be diverted to other uses, and that the quantity offered to the consuming countries should be so regulated as not to exceed their requirements. I proposed that the State, which collected then, as it collects still, the Land Tax at the Custom House, should take this tax in kind, and that the total of the tax should be equal to the excess of the estimated production of the coming season over the ascertained universal consumption of the last. I insisted on the fact that currants were a natural monopoly of Greece, and as such they were entitled to the advantages of a monopoly. I showed that the fall in price to much below the cost of production was not due to the competition of a similar article produced in another country, but to the competition of the Greek currant producer against himself. I illustrated this argument by comparing the currant grower in his collective capacity to the sole baker of a small community, who, having customers for 100, offered for sale 110 loaves of bread, and who, in endeavouring to 
force the sale of the extra 10, reduced the price of all to less than one half of what it cost him to produce them.

This plan drew the attention of the general public no more than the others; and all remedial schemes were forgotten with the advent of the French demand, which seemed to superficial observers to have put an end to the crisis. I, however, was under no such illusions. I was certain that the crisis was only postponed, and I lost no opportunity in saying so to my countrymen, and in pressing my plan on their attention. The immense efforts of the French to restore the productiveness of their vineyards to their former level had made it plain to my mind that France could not be relied upon as a permanent customer. I foresaw the terrible crisis which eventually came on and brought the country to the verge of ruin. In February, 1889, I wrote that if nothing were done to regulate the export of currants, "the time will come when no merchant will dare to touch them, even at 50 drachmae per thousand Venetian pounds" $(2 s .8 d \text {. per cwt. })^{1}$. This time came four years later. In May, 1893, the lowest price in the London market was 21s. per cwt.; in November of the same year, following an abundant crop in Greece and a very large vintage in France, the same currants were offered at $6 s$. only. The duties, taxes, freight and other charges amount to over $8 s .6 d$. per ewt., so that not only was there nothing left to the producer against the cost of production, but the shipper, who bought and sent the currants to the English market, was losing all that he had paid for them, plus $2 s .6 d$. per cwt.

This unprecedented fall in the price of the most important product of the country had disastrous and far-reaching consequences. Scores of the oldest and of the most important currant houses of Greece came down like houses of cards; and the whole commercial class of the Peloponnesus, and almost of the whole kingdom, reeled under the terrible blow. The capital value of the currant plantations was estimated before the crisis at over $£ 20,000,000$, and this value had disappeared, with the disappearance of all net income. Mortgagees could get no interest on their loans, and no one would lend a farthing on the security of a currant plantation. Men who were considered rich six months earlier found themselves beggars. Many of the large proprietors, who were unable to cultivate their lands without employing hired labour, offered to let them for nothing in order to save them from ruin for want of cultivation. Even the classes that had no immediate connection with the production or the trade of currants shared the fate of those immediately concerned. The foreign gold brought into the country by the sale of currants was the life blood of almost every industry, and when this blood ceased to flow, almost every industry was paralysed. Wages, rents, professional incomes, fell by over 50 per cent.; and the depreciation of paper money, a natural concomitant of poverty and of want of credit, reduced the purchasing power of the curtailed incomes still further. This state of things was

$$
1 \text { " Ephemeris," Athens. }
$$


brought about partly by the increase of production, which in 1893 attained the total of 165,000 tons; but mainly and chiefly by the decrease of the consumption in France, due to the abnormal increase of her wine production, and to the already mentioned legislative restrictions in the use of currants for wine making.

It was at this time only that the people and the rulers of Greece realised the situation. All other questions sank into insignificance in the public mind in face of this catastrophe. There was a consensus of opinion that something had to be done; but there was very little agreement as to what that something should be. The Chamber of Commerce of Patras, the centre of the currant trade, nominated a committee to report upon the matter. As a member of this committee I was charged by my colleagues to draw up its report. The committee adopted unanimously my report, which was in favour of the State regulation of the export of currants. The regulation was to take the form of the retention of a certain percentage on the quantity exported; such percentage to be equal to the excess of the estimated production over the ascertained consumption of the previous season, and to be deposited by the shipper in Government stores at the time of shipment. The currants so retained were not to be exported in their natural state, but they were to be sold and used solely in the country for manufacturing purposes, under the control and the supervision of the authorities. The Chamber of Commerce, accepted the report, and recommended it to the consideration of the Government.

Up to that time the currant merchants were more forward than the growers in demonstrating to the Government and Parliament that their intervention had become absolutely necessary. The feeling of these high authorities, however, was that the currant merchants were a perfect nuisance. They thought that the disease would find its own cure if it were allowed sufficient time; and this attitude of an absolute laisser faire on the part of the Government was upheld by the influential part of the Athenian Press.

The crisis becoming day by day more acute, the growers began to show greater interest in the question. The larger proprietors, men belonging mainly to the educated classes, approached the merchants, and asked to be informed as to the remedial measures advocated by them and supported by the Chamber of Commerce. A public meeting was held in the town of Patras, in the beginning of November, 1893, and resulted in the appointment of a Currant :Growers' Committee, composed of three barristers and myself. This committee placed itself at the head of the movement and started a vigorous educational propaganda through the Press and by public meeting. It addressed several memorials to the Chamber of Deputies, strongly supporting the State regulation of the export of currants, and showing the danger of the policy of doing nothing. The direction which the intervention of the State was to take was sketched out in clear and well-defined lines.

At the re-assembling of the Chamber the Government was questioned, 
and a debate ensued, resulting in the appointment of a Parliamentary Committee of forty members, representing currant-producing constituencies: The committee reported in favour of State intervention, and recommended the adoption in the main of the measure proposed by the Patras committee. In January, 1894, Mr. Tricoupis, the Premier, brought in a Bill adopting fully the principle of the retention of the surplus, accompanied by a convention with the Monopoly Company of Athens, by which the management of the retention was placed in the hands of the Company at what were then considered excessive advantages to it, as a return for an undertaking on the part of the Company to lend, at moderate interest, six millions of drachmae to the currant growers on the security of their growing crops.

The Bill, which was read a first time, did not please anybody. The retention clauses, the corner-stone of the Bill, were loosely drawn. A minimum of 140,000 tons was fixed as the quantity exportable, and the advocates of retention found this minimum too large for the probable requirements of the consumers. On February 19th I wrote to the Premier that the Bill had disappointed the expectations of all concerned, and I pointed out the most glaring of its defects, which, in my opinion, rendered its failure absolutely certain. ${ }^{1}$ Meetings were held in many currant districts, and the Bill was denounced with great determination and vehemence. Strong opposition was also manifested in the Chamber, while the Press, including the ministerial organs, had very little to say in its favour. In face of this determined opposition the Government withdrew the Bill, and brought in another of a more limited scope. The convention with the Monopoly Company was abandoned. The principle of the retention of the surplus was accepted, and the quantity to be retained was to be fixed more in conformity with our views. A special Administrative Board, representing the currant growers, was to be created for carrying out the Act. The Ministry, though voting solidly for the Bill, left its supporters free to vote as they pleased. Several voted against the Ministry, and the Bill was lost by a majority of two.

The rejection of the Bill was followed by a further fall in the price, until in the month of April the lowest point on record was reached. The currants were offered in certain parts of Greece at thirty depreciated paper drachmae per 1,000 Venetian pounds, out of which price one-half had already been paid for municipal taxes and for cartage to market, leaving to the grower about $9 d$. per cwt. with which to pay the cost of production, amounting to more than fifteen times that sum, without allowing one penny for interest on capital.

This unprecedentedly low price stimulated a demand from the South of Russia, to which country several shipments had been made out of the crop of 1893. The total quantity shipped exceeded 10,000 tons, and this fact tended to kindle in the ever-buoyant Greek breast

1 I had seen Mr. Tricoupis, at his own wish, two months earlier, and had explained to him my plan. 
the most extravagant hopes for the future. The anti-retentionists were elated. "We told you so," they said; "the low price was bound to attract consumers for the surplus." Their elation was but short lived. The Russians could only take currants at a price much lower than the cost of production, and therefore their custom would not help the grower. He was hopeful, all the same, and seemed content to wait and see what this new customer would do for him.

The new crop of 1894, before it was gathered, was estimated to be about 25 per cent. shorter than that of 1893 ; and the growers hoped that by the diminution of supplies through this natural shortage, and the increase in the demand from Russia, they would be able to obtain remunerative prices. These hopes were doomed to early disappointment. Prices opened, indeed, much higher than those ruling in the market at the close of the season for old fruit; but in less than a fortnight they fell nearly 50 per cent., and the agitation in favour of State intervention commenced afresh with renewed vigour.

In the meanwhile, the currant committee of Patras had succeeded in forming a " Currants Union," in which growers had taken a prominent part. The educational propaganda of this body and of the retentionists generally had never ceased, and it had been splendidly helped on by the realisation of almost all our predictions. The prospect of the loss of another crop made the poorer class of growers desperate; and the King's writ did not run at all smoothly in the province of Elis, erstwhile the richest, now the poorest, through being the largest currant producing district. The newspapers were full of heartrending reports from the places in distress, and one of them had assigned special columns to these reports, under the heading, "From the Land of the Starving."

The discussion in the public press showed a growing addition to the ranks of the retentionists, while the opposition was getting correspondingly weaker. The Acropolis, one of the highly respectable Greek daily papers, and the most enterprising and influential, sent its manager, Mr. Gabrielidi, to England, with the object of ascertaining the opinion of the currant merchants and dealers. This gentleman had interviews with all the leading members of the London dried fruit trade, importers, dealers and brokers; and all of them, without a dissentient voice, supported the retention scheme. It may appear at first sight paradoxical that the buyer and distributor of a commodity should advocate a measure the immediate result of which would be to raise the price of that commodity against himself. But, on closer examination, it will be found that the views of these practical business men, admirably put forth at the time by the London Produce Market Review, were compatible, not only with their position, but also with their interests and the interests of the consumer whose agents they practically are. "The consumer," reasoned the dealer, "has no interest in the ruin of the producer of an article which he wants to buy. Currants cannot be produced at these prices, and the natural conse- 
quence will be the restriction of their production. The diminution of supplies will necessarily lead to an undue appreciation ; and this I consider a misfortune, both for myself and for the consumer, and, therefore, I am in favour of any reasonable measure which will enable the grower to sell at a remunerative price, in order that he may continue to produce."

The views of the English currant traders were placed before the Greek public in the columns of the Acropolis, and have exerted a great influence in reconciling that part of the opposition which was due to timidity and want of information. The indefatigable Mr. Gabrielidi made also a pilgrimage to Cambridge, with the hope of obtaining some authoritative pronouncement, one way or the other, in that ancient seat of Economic Science. He interviewed Professors Sidgwick and Marshall ; but these eminent and learned gentlemen expressed divergent opinions, and though these were put before the Greek public, they neutralised one another, and have not helped to advance the question. In his search for more light, Mr. Gabrieldi addressed to several other Professors of Political Economy the following letter :-

"Sir,-Encouraged by the world-wide and humanitarian views which animate and inspire the distinguished exponents of science in England, I take the liberty to ask your enlightened opinion upon a question vitally affecting my poor little country. I crave in advance your indulgence in thus venturing to encroach upon your valuable time. The currant is one of the most important products of Greece; it produces more than half the total value of our exports. This product, of which Greece has been granted by nature the absolute monopoly, is at this moment in a most critical position in the markets of the world, for the simple reason that the production exceeds the present needs of the consumers. The surplus stock, though not exceeding 15 to 20 per cent. of the total produce, competes with the balance, and brings about such a fall in the price of the whole as to leave no margin whatever for the labour and part of the outlay of the cultivator. In the face of this desperate condition, which spells ruin and starvation to a million of people, the question is being discussed amongst the more intelligent of the growers; amongst the merchants and amongst our public men, as to whether the situation does not call for the intervention of the State, and whether a temporary measure by which the authorities would be empowered to retain at the Custom House, from every shipper, a proportion equal to that of the surplus which destroys the value of the whole, is not imperatively called for. The wants of the consuming countries and the probable yield of the currant plantations being pretty well known in advance, it is proposed that the State should not allow the shipment of a quantity larger than the requirements of the consumers, and in this way enable the growers to sell, through the same channels as now, that portion of their crop which the consumers require, at a fair price, covering at least the cost of its production. The surplus retained by the authorities would be rendered unfit for all but wine making, distillation or other industrial purposes, and would be sold for account of its original owners for what it might be worth. This measure would remain in force until the consumption comes up to the production. On this economic question I solicit your valuable opinion, of which I intend to be the interpreter to my countrymen. The proposed measure, though approved of and demanded by the majority of the producers, has met with 
some opposition from a portion of the people and of the public press. It is to bring about an approximate unanimity on this or some other plan that we desire to place before the public the opinions of eminent politital economists. In conclusion I must again emphasise the fact that currants are not and cannot be produced in any other part of the world."

The answers of the several eminent men to whom this letter was addressed were no less divergent than the views of Professor Sidgwick and Marshall. Some of them wrote that State intervention under the circumstances was perfectly legitimate and advisable; and others that it was not, and that there was nothing for it but to trust to the slow operation of natural forces.

On the re-assembling of the Chamber the ball commenced again to roll. Not a day passed without some kind of discussion on the allabsorbing topic being initiated, either by an interpellation to the Government, or by a protest against its inaction, on the part of some member representing one of the distressed constituencies. At the end of November, 1894, the Premier introduced a resolution affirming the principle of retention; and this resolution was passed after a long discussion by seventy-four to sixty-nine votes, the leaders of all parties voting in its favour. A special committee of members was nominated to draft a Bill giving effect to the resolution. On the introduction of the Bill it was found that it did not meet with the approval of all the supporters of the resolution, and the first reading was refused by sixty-two to forty-five votes, more than thirty members of those who had voted for the resolution not voting for the Bill. The Chamber soon separated for the holidays, and it did not meet again until after a general election, a dissolution following the resignation of the Tricoupis Ministry, in January, 1895.

The demand from Russia at the very low prices ruling during the three first months of the season (September-December) had been most encouraging, and superticial observers argued that Russia was capable of absorbing, and would eventually absorb, not only the surplus, but as many currants as Greece could produce. This argument was clutched at and made the most of by the anti-retentionists, some of whom, having made a collection of currants, and abandoning their occupations, started for Russia as amateur commercial travellers in the interest of currants. They went round many parts of Southern Russia, on the self-imposed mission of introducing the use of currants to the subjects of the Tsar. They distributed gratis small packets of fruit to loafers at railway stations, and harangued them on the valuable properties of currants. They sent back to Greece such glowing accounts of their achievements that simple folks were honestly convinced that there was an end of the crisis. To dispel this illusion we pointed at the very low prices offered by the Russian buyers, and told the unreasoning enthusiasts, who were perambulating in Russia, that the Russians, numbering more than one hundred millions, would have no difficulty in eating the whole crop of currants, if they could get it 
for nothing ; but that there was no reason for hoping that they would take any appreciable quantity at a price which would pay for the cost of production and leave a small margin to the grower. ${ }^{1}$

These expostulations had no weight with the anti-retentionists, who persisted in ventilating their optimistic views, and succeeded for a time in deluding a large number of people into the belief that the currants question had found an abiding solution in the demand from Russia. In January, 1895, the currant missionaries, as they were most aptly christened by the people, were said to have reported that there was no limit either to the quantity of currants which Russia would require, or to the price which she was prepared to pay for them. On the strength of these reports a violent speculation set in, and prices were widely pushed up by irresponsible gamblers in Greece, regardless of the prices ruling in the countries of consumption. This bubble helped to damp the agitation in favour of State intervention for a few months; but the bubble burst as soon as the speculators were called upon to pay for their purchases. They looked about for buyers on whom to unload, but they looked in vain. The unlimited demand from Russia turned out to be a myth, and the offer of large quantities of fruit to the other markets brought prices down to their former level in no time.

When the new Chamber met in June the agitation in favour of State intervention was again at fever heat. Attempts to distrain in certain parts of Achaia and Elis for 'taxes or private debts were frustrated by the peasants, who, imitating the Irish, put their women folk in front to attack the bailiffs with broomsticks and other less innocent weapons. No sooner was the House constituted by the election of its President and other officers, than half a. dozen private

1 It was not long before the absolute correctness of this view was proved to demonstration. As soon as the price of the fruit rose above starvation point, the demand from Russia came to an end. Later on, the Russian Government, appealed to by the Bessarabian wine growers, ordered an investigation, the result of which was to prove to the satisfaction of the Minister of Finance that a large part of the currants imported were used principally by the Jews in the manufacture of wine. By a Ukase published in the beginning of 1896, certain restrictions, similar to those of the French Griffe law, were imposed on the manufacture and sale of wine made from currants. This measure failed to satisfy the Bessarabians, who continued to agitate against the importation of currants. The Government yielded at last to their clamour, and imposed a prohibitive duty of $18 \mathrm{~s}$. per cwt., to be levied on and after the 13th of January, 1897. Shipments on consignment were rushed in in December, 1896, to avoid the payment of duty; and on the day the duty commenced to be levied there had been accumulated at Odessa and Nicolaieff a stock of about 12,000 tons. No sooner did the price advance to about 10s. per cwt., free of duty, a price barely covering two-thirds of the cost of production, than the consumption in Russia fell aimost to nil. Though the stock in Russia was protected against the competition of new importations by a duty of twice as much as the market price, the holders of 1t, not finding customers in Russia, had to sell it at a loss to exporters for other countries. Of the 12,000 tons mentioned above, more than one half was sold out of Russia at 10s. per cwt. and under. Of course not an ounce of currants has been imported by Russia since the 12th of January, 1897. 
Bills were introduced. Mr. Delliyanni had obtained an overwhelming majority at the elections, and was Prime Minister. Although he had voted in favour of the principle of retention in the preceding Session, he was at heart opposed to State intervention; and these private Bills, though introduced principally by supporters of his Administration, obtained only half-hearted support from the majority, and they were all rejected one after another.

At this juncture the Patras currant growers and merchants elected and sent to Athens an influential deputation. The deputation had interviews with all the Ministers and the leaders of the Opposition. The spokesmen of the deputation were very frank and outspoken; and they told these statesmen, and especially the Premier, that unless the Retention Bill became law before August, there was fear of social war in certain parts of the Peloponnesus. They further told the Prime Minister, who was Chancellor of the Exchequer as well, that he must not expect to collect taxes in the distressed currant districts. The same language was used in the Chamber, mostly by supporters of the Government. The Premier said that he was shocked at these revolutionary warnings, but he saw that he had to deal with a desperate situation, and with a population maddened by suffering and want. It was evident that promises and soft words and long disquisitions on the propriety of State intervention could avail no longer. On the very day of the rejection of the last of the private Bills he brought in a Government measure, which eventually became law, after a long discussion and several amendments. The main provisions of this Act were the following: $(A)$ In consideration of an abatement of four drachmae per thousand Venetian pounds in the Land Tax collected at the Customs, the shipper has to produce a receipt that he has. delivered in kind to a Government store 15 per cent. on the quantity he declares for exportation; failing such a receipt, he must deposit in money thirteen and a half drachmae per thousand pounds on the quantity so declared, such deposits to be converted into currants, whenever the Government are able to buy them, irrespective of quality or growth, at or under ninety drachmae per thousand Venetian pounds. $(B)$ The currants delivered to or purchased by the Government must be used exclusively within the country for industrial purposes. $(C)$ The surplus accruing from the sale of such currants by the State over the loss of revenue, due to the aforesaid abatement, and the expenses of carrying out the Act, shall form a special fund, to be devoted to the interests of the currant growers, in a manner to be determined later on by the Chamber.

This Act was hailed as a deliverance by the poor growers, who, reduced to a helpless state, were eager to clutch at any straw. I, however, found it wholly inadequate to cope with the situation, and predicted its failure as soon as I read its provisions. I considered the percentage of 15 per cent. too small in face of an estimated surplus of double that quantity. But the greatest blot of the Act was, in my 
view, the limit of price over which there was to be retention not of currants, but of money. This limit of ninety drachmae per thousand pounds is but three-fourths of the average cost of production; and supposing, as the Legislature erroneously supposed, that the limit was to be the minimum market price, it still left the grower only a little better than he was. I wrote at once denouncing the Act, ${ }^{1}$ and concluded as follows: "It is my fervent wish that my fears may prove groundless, and that the future may show the Act to be adequate, as many of my fellow workers seem to believe. I should have much preferred to keep my fears to myself, in order that the hopes for better times of the sorely tried growers might not be shattered; but considerations of far greater moment compel me to speak out, for I still think that the scientific and efficient retention is not for ever buried in the clauses of this Retention Act."

I did not have to wait long for the realisation of my worst fears. The shipment of new currants commenced on August 28th; and for some time the lowest market price kept just above the limit of ninety drachmae and, therefore, instead of retention of currants, there was retention of thirteen and a half drachmae per thousand pounds in money. The surplus was thus not reduced by a single ounce; but the capital of the exporters, so necessary to sustain the stability of the market, was being reduced at the rate of 15 per cent. on their exports of currants, valued at ninety drachmae per thousand pounds. On September 10th, I wrote again in the Acropolis: "There can be no hope of an improvement in prices so long as there is no retention of fruit. Instead of currants, of which we have a surplus, our Government retains money, which is scarce, and of which the currant market is in sore need. It has been oddly believed in Patras and elsewhere that the ninety drachmae were to be the point below which the price could not fall, because, some unthinking people said, the State would come in to buy at this price for the retention stores. But the Retention Act makes, obviously, the ninety drachmae the highest and not the lowest point; for, over this point, there is no retention of currants, i.e., there is no diminution of supply, but, on the contrary, there is retention of money, and consequently diminution of demand, by the contraction of the means of purchase, i.e. of capital."

The natural result of the operation of this unwise clause followed soon. The markets of consumption became flooded with goods, and prices fell to much below the limit fixed by the Act. It was only then that exporters found an interest in paying the retention in kind instead of in money. By the end of the year the whole country was convinced that the ninety drachmae limit was nothing less than a device of the anti-retentionists to compass the failure of the Act, by depriving the growers of the benefits which the retentionists had promised them. On the reassembling of the Chamber a short Bill was introduced rescinding this clause, and it was passed with little oppo-

${ }^{1}$ Acropolis, July, 1895. 
sition. The Act, as amended, has been annually renewed, and it is in operation now. At its last renewal an amendment was incorporated to the effect that the retained currants shall not be used for the production of Wine, Syrup, or Must. These restrictions were imposed at the instance of certain deputies in the interest of growers, with a view to compelling Wine, Must, and Syrup makers to buy the currants in the open market, instead of buying at the low prices at which the retained fruit is sold. The amendment was opposed at the time on the ground that its sole effect would be to kill a rising national industry, and results have justified this opposition. With the cheap currants of the retention as raw material, Wine, Must, and Syrup could be made and exported at a profit. But it has been found impossible to compete with similar products in foreign markets, if the raw material had to be bought in the open market at high and constantly fluctuating prices. Hence, these industries have been all but abandoned. It is to be hoped that in the interest of the country, and, above all, of the currant growers themselves, these restrictions will be removed at the next renewal of the Act.

The currant crisis reached its acutest stage in 1893-4, when one thousand Venetian pounds of good merchantable currants could be and were bought at thirty drachmae, or $1 s$. $6 d$. per cwt., first cost. Including that, and excluding the present crop, there have been since five currant seasons, which I divide into three groups. In Group I. I place the crops of 1893 and 1894, which were subject to no retention; in Group II. I place the crop of 1895, which was subject to a partial retention; and in Group III. I place the two last crops, which were subject to the full retention of 15 per cent. on the quantity exported. I append a table showing the results of the three groups.

Group I.

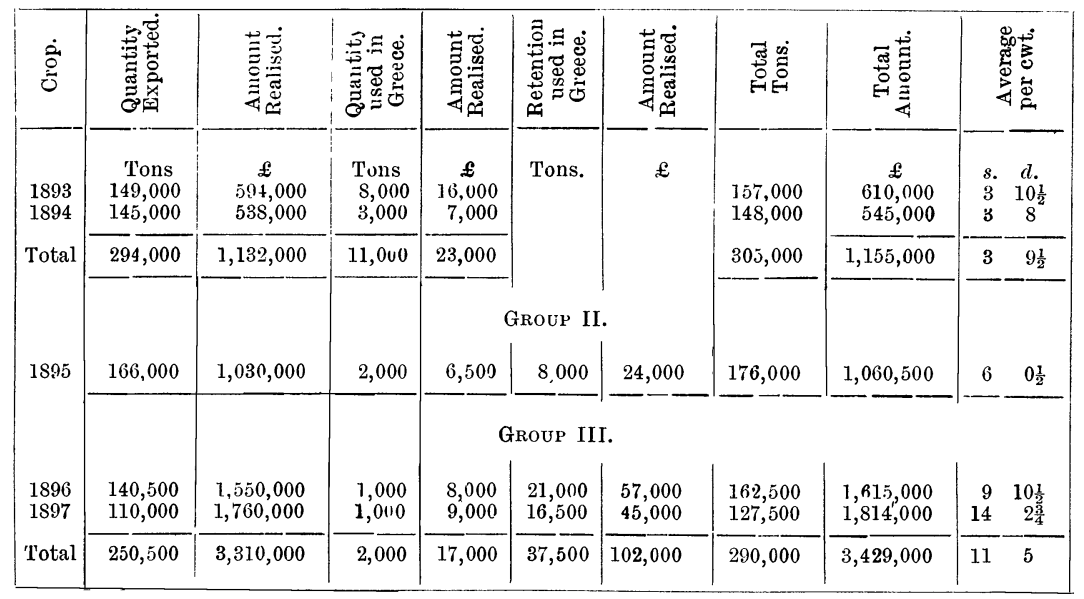

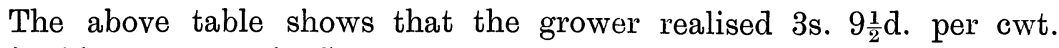
for his two crops in Group I. (no retention); that he realised 6s. $0 \frac{1}{2} \mathrm{~d}$. 
per cwt. for his crop in Group II. (retention in kind under 5 per cent.), with some prospective advantage to himself out of the net proceeds of the currants retained; and lastly, that he realised 11s. 5d. per cwt. for his crops in Group III. (15 per cent. retention), also with a prospective advantage out of the net proceeds of the 37,500 tons retained. To arrive at the net price realised by the growers collectively, I have not taken into consideration the price at which they themselves may have sold to exporters or speculators. My calculations are based, firstly, as to the quantity exported, upon the price which the exporters collectively realised by the sale of the fruit abroad; and secondly, as to the quantity used in Greece, upon the price paid by the manufacturers. This manner of arriving at the average price cannot pretend to absolute accuracy, but it is the best available, and, being the same for all three groups, it is perfectly safe as a basis for comparison. It should be stated here that the growers received this average price on their whole crop, including, that is to say, the quantity retained, with which they have absolutely nothing to do, since it is the exporter who buys the fruit in the open market and delivers it to the retention stores, adding the outlay to the cost of the exported goods. It should also be noted that the smallest crop (1897) brought to the growers the most satisfactory return. It might be supposed that the difference between the 3s. $8 \mathrm{~d}$. for the 1894 and the 14s. $2 \frac{3}{4} \mathrm{~d}$. for the 1897 crops came out of the consumer's pocket. As a matter of fact the consumer paid in 1897 no more or very little more for his currants than he paid in 1894 . The extraordinary low prices in 1893-5 were considered by the distributors as quite abnormal, and, therefore, of short duration, and neither the wholesale dealer, nor the retailer reduced their selling price to a corresponding degree. The immense difference during the low-priced seasons went to swell the profits of the middlemen, of whom the retailer had the lion's share, rather than to reduce the consumer's currant bill.

It is estimated that by the end of the currant season the special fund established by the Retention Act will have available a sum of about $£ 150,000$. This amount represents the surplus paid into the fund out of the proceeds of the retained currants, after the payment of all expenses and the refunding to the Exchequer of the Land Tax abatement of four drachmae per thousand pounds, on all the currants exported since the Act came into force. It should be observed that the currants retained and sold for use in Greece for industrial purposes, though of the commonest quality, realised on the average a little over 2s. 9d. per cwt. This is just 1s. per cwt. less than the average price realised for all the qualities of the crops in Group I., and 1s. 3d. more than the lowest open market price during those two seasons. It is beyond doubt that a much higher price can be obtained for these currants, if the Legislature would place the retention authorities in a position to sell a given quantity at a fixed price for a series of years. In fact, many good offers have already been 
made on this condition, one important firm alone offering to contract at nearly double the price realised, for twenty thousand tons each year. The Retention Act has created a most promising industry. Numerous distilleries have sprung up all over the country, using only currants as raw material, and producing the finest alcohol in the world. Those competent to judge affirm that the eau de vie de vin obtained from currants cannot be surpassed by the finest cognac that France can produce. When this offshoot of the currant industry has had time to develop, it bids fair to contribute to the national wealth as much perhaps as the parent industry itself.

The remarkable results enumerated above speak for themselves, and need no comment. Incalculable, however, as have been the benefits to the growers from the Retention Act, they would have been greater still, had its operation not been handicapped all along by the many defects of the measure and its crude and unworkable provisions. The Bill had been drafted and proposed by its author, and it was passed by the Chamber with the certainty of its failure, and as a sop to a popular demand which it was considered dangerous to resist. No care, therefore, was bestowed upon the structure of the Act, and its working suffers, to the present day, from the sins of its inception. The defects of the Act, and especially its provisional character and the arbitrary fixation of the percentage retainable at 15 per cent., irrespective of the relations between supply and demand, have been constantly assailed by all those who are competent to express an opinion. They have been likewise condemned by both the Currant Growers' Congresses held at Patras in 1896 and 1898. It is now agreed, almost on all hands, that what is required is a law running on parallel lines with the Bill drafted by me in 1893, at the request of the late Mr. Tricoupis, and recommended to the Chamber, in February, 1894, by the Currant Growers' Union. The main provisions of this Bill were: (1) A fixed retention of 3 per cent., whatever be the extent of the crop, with the object of improving the quality by a more careful sifting and cleaning of the fruit. Refuse currants, clean and free from foreign substances, to be accepted as good delivery to the retention stores. (2) A further retention equal to the surplus of the estimated supply over the estimated requirements of the world. The visible stocks at home and abroad, on the 31st of July; with the estimates of the coming crop, to be taken as the estimated supply; and the universal consumption of the preceding twelve months, plus 5 per cent., to meet a probable increase, to be taken as the estimated requirements. The figures to be finally fixed by a representative committee, on the 21st August, on data collected by the Government. (3) The administration of the Act to be placed in the hands of a Currant Bank to be forthwith established. The money already available, together with the proceeds of the retained currants still unsold, to form the nucleus of the bank's capital, which shall go on increasing by the addition of the proceeds of the currants retained in the ensuing years.

No. 36.-VoL. IX

$\mathrm{U} \mathrm{U}$ 
All currant growers to be shareholders of the bank in proportion to the areas which they cultivate. The bank to lend to its shareholders at moderate interest, on the security of their growing crops, small sums of money, for purposes of cultivation, repayable in October.

The original Bill, as introduced to the Chamber in 1894, provided also that a minimum and maximum lowest price should be fixed for the commonest quality, which governs all others, in order that production and consumption should be unable at any time to oppress one another. This can be secured by the retention authorities being empowered to sell in the open market, out of the retained currants, whenever the lowest price rises to over the maximum fixed; and to buy in the open market, with retention money, whenever the lowest price falls to under the minimum. The minimum was fixed by the Bill at 120 drachmae per 1,000 pounds, this being considered to be the average cost of production, while the maximum was fixed at 200 drachmae, equal to about $15 \mathrm{~s}$. per cwt., free on board Greece. The margin between the two limits was considered sufficiently wide for the exercise of commercial enterprise, in an article enjoying natural monopoly. This provision has not so far met with approval, nor is it very popular with the growers, who are naturally desirous of being left free to exact as much as they can out of the consumer. I consider, however, this provision a necessary corollary to a State regulated monopoly, and the artificial restriction of supply, which might conceivably, say, on a a sudden demand from an unexpected quarter, place the consumer at the mercy of the producer.

The new Chamber, which meets in a few weeks, will, it is to be hoped, deal with the question. in a broader and more statesmanlike manner than the last; and that, in any case, it will put an end to the provisional character of the measure, and leave the fixation of the percentage of retention to be determined at the proper time, in relation to the estimated surplus of the supply over the estimated demand.

Theodore A. Burlumi

P.S.- Since this article was written the Greek Government introduced to the Chamber of Deputies a Bill based entirely on the lines indicated above. This Bill became law in July last and it is now in operation. The three main provisions of my own Bill have been adopted. The Act is to be in force for ten years. The minimum percentage fixed by the Act is 10 per cent. on the quantity exported. A committee representing the currant growing districts shall be called together in August, in each year, to advise as to whether the minimum should be increased, the ultimate decision resting with the Cabinet. In no case, however, can the percentage of retention exceed 20 per cent. This limit I consider to be the greatest blot of the Act. It is entirely opposed to its spirit, for in the event of an abundant crop the maximum percentage may prove sufficient to attain its principal object. The Government and Parliament, though accepting unreservedly the principle of the retention of the surplus, proceeded to 
its application with halting steps and failed to carry it to its natural conclusion. I have little doubt that before long the maximum of 20 per cent. will have to go by the board.

T. A. B.

\section{LETTER FROM JAPAN (continued from No. 35).}

\section{Politics and Finance.}

THE year 1897 began without any great political excitement except the gold standard question. In May, the Government succeeded in selling 43,000,000 yen of war loan bonds to a London firm, thus paving the way for foreign investment in our negotiable instruments. This gave some consolation, and served as a stimulus to those who were in want of capital. But in the political world there was steadily upheaving a disruption between the followers of Count Matsukata (the Premier) and the progressive party led by Count Okuma (the Minister of Foreign Affairs). The latter resigned in November, and it was the intention of Count Matsukata to augment the revenue by about 25,000,000 yen by the increase of the rate of the land tax by 1 per cent., and of that on sake by 3 yen per koku. When the Parliament assembled in December, the liberal, progressive, and national parties, into which the House is divided, all united in bringing forward a vote of want of confidence in His Majesty's Government. On Christmas day the Parliament was dissolved, and until January of the following year the country was without a Cabinet. On the 12th of that month Marquis Ito kissed the hand of His Majesty as Premier, and Count Inouye as the Minister of Finance. The liberal party seemed to have made some proposals to the new Cabinet. Failing in this, their attitude became gradually unfavourable towards the Government.

Meanwhile the Finance Minister did much in alleviating the condition of general economy, and exerted all his influence in suppressing the sudden expansion of expenditure, especially that on the Army and Navy. His success in this as well as in getting the remnant of the Chinese indemnity to be paid up all at once in May must not be overlooked. That month saw the opening of the Parliament, which was by no means peaceable, as the spirit of opposition was daily gaining strength. The most important questions were the increase of the land tax and the extension of the franchise, which involved the increase of members for boroughs and the abolition of the registration of names of the voters by ballot. These two were not distinct but in fact had one common object, because by the reform the predominance of the agricultural interest in the House will be weakened, thereby affording facility for the passing of the land tax bill. But more from political considerations the land tax bill was negatived on the 12th of June, followed by an Imperial order for dissolution. The country had 